\title{
THE EFFECT OF THE USE OF IMAGE CARD MEDIA ON SHORT STORY WRITING ABILITY
}

\author{
Agus Sulaeman ${ }^{1}$ \\ University of Muhammadiyah Tangerang \\ sultanwahyu13@gmail.com \\ Enawar \\ University of Muhammadiyah Tangerang \\ enawar.abah@gmail.com
}

Sulaiman, A. and Enawar. (2022). The Effect Of The Use Of Image Card Media On Short Story Writing Ability . Journal of English Language and literature. Journal of English Language and literature, 7(1), 19-26. doi: 10.37110/jell.v7i1.139

Received: 11-01-2022

Accepted: 22-01-2022

Published:03-03-2022

\begin{abstract}
The purpose of this study was to analyze the differences in students' Indonesian writing skills in short stories material who received flash cards and students who received conventional learning methods. The population in this study was class VIII SMP Aruslan, Sukamulya District, Tangerang Regency, for the 2021/2022 academic year. The sample in this study were students of class VIII.3 and VIII.4 totaling 60 students with a sampling technique using purposive sampling, two classes were selected, namely the experimental group and the control group. The experimental group received a picture card learning media (flash card), while the control group received conventional learning. The method used in this study is a quasi-experimental method with a nonequivalent control group design. The research instrument given was in the form of a test consisting of 10 questions in the form of an essay. Analysis prerequisite test using Chi Square test and Fisher's exact test, it was found that both samples were normally distributed and homogeneous. From the calculation of statistical tests obtained tcount $>$ ttable $(2,48>1.99)$, then $\mathrm{Ho}$ is rejected and $\mathrm{H} 1$ is accepted at a significant level $=0.05$ with degrees of freedom $(\mathrm{db})=64$. So it can be concluded that there are differences in students' short story writing abilities. which is taught with the media of picture cards (flash card) and which is taught by conventional learning methods. Thus, it can be concluded that there is an effect of using flash card media on students' short story writing skills.
\end{abstract}

Keywords: Word : Picture Card Media

\section{INTRODUCTION}

Less interesting learning experienced by teachers who do not understand the needs of these students in the characteristics, as well as in the development of knowledge. Good learning can be supported by a conducive learning atmosphere and good communication between teachers and students. In addition, the learning process is often faced with learning materials that are difficult to describe and outside the daily experience of students. So that learning materials are difficult to teach teachers and difficult for students to understand. While students are trained to understand the concepts covered in the

${ }^{1}$ Corresponding Author 
curriculum, especially Indonesian language subjects as a whole, it is not easy.

In the learning process the media has a contribution to improve the quality and quality of teaching. The presence of the media not only helps the teacher in delivering the teaching material, but also adds value to the learning activities. This applies to all types of media, both sophisticated and expensive or simple and inexpensive media. Media picture cards (Flash cards) can be used as teaching aids in various fields of study. Drawings in the form of photographs, paintings/drawings, and sketches (line drawings) can facilitate understanding (eg through elaboration of structure and organization) and strengthen students' memory when writing short stories. The ability of images to manipulate time and space can invite students to travel anywhere, even though they are limited by classrooms.

According to Arsyad (2011:119) Flash card comes from English, Flash (fast), Card (card). So Flash card means fast card. Flash cards are simple media that use small cards that contain pictures, text or symbols that remind or guide students to something related to the picture. Flash cards or Education Cards are picture cards equipped with words, which was introduced by Glenn. Doman, a brain surgeon from Philadelphia, Pennsylvania. The pictures on Flash cards are grouped, among others: animal series, fruits, clothes, colors, shapes, numbers, and others. The learning cards are played by showing them to the children and reading them out quickly, in just 1 second for each child's card.

Flash cards are large cards, usually using a rather thick, stiff paper and usually A4 size. Flash cards show pictures or written words, usually Flash cards consist of devices grouped according to type or class, for example groups of pictures of food, fruits, pictures of a person performing ablution, means of transportation, and others. So the authors conclude that the Flash card learning media is a visual learning media in the form of cards containing pictures or writings that can direct students about the material being studied, so as to accelerate understanding and can strengthen students' memory.

Writing is a productive language skill, meaning that writing produces language symbols in written form. (Tarigan, 2008: 3) suggests that "Writing is a productive language activity and can be used to communicate indirectly". In this modern life, it is clear that writing skills are needed. It would not be an exaggeration to say that writing skills are a characteristic of an educated person or an educated nation.

Meanwhile, according to Hasani (2005:2). said that writing is a language skill that is used to communicate indirectly. Writing is a productive and expressive activity, so writers must be able to utilize the ability to use deaf grammar, language structure, and vocabulary. So writing is a process of expressing thoughts, feelings, sensations, fantasies, desires, beliefs, and experiences and arranged with graphic symbols in writing for communication purposes.

Meanwhile, according to Sulaeman (2019: 59). Writing is a complex ability, which requires a certain amount of knowledge and skills. What is meant by a number of knowledge and skills in writing short stories is that we have to choose a topic to limit it, develop ideas, present logically arranged sentences and paragraphs, and so on.

Writing is an activity that is productive and expressive, because the result of writing is usually the experience of the author. Miller says, "Even though they write about themselves, they don't write for themselves. They also write to share their experiences with reading." Tarigan (2008:1) There are four language skills that we need to master in order to communicate with others, namely: Listening skills, Speaking skills, Reading skills, Writing skills . Each of these skills is closely related to the other three skills in various ways. In acquiring language skills, we usually go through an orderly relationship. At first in childhood we learn to listen to language then speak, after that we learn to read and write. Listening and speaking we learn before 
entering school. The four skills are basically a unit, a single chess.

Each language skill is closely related to the processes that underlie language. A person's language reflects his thoughts. The more skilled a person is in language, the clearer his way of thinking will be. Tarigan argues, "Skills can only be acquired and mastered through practice and a lot of training. Practicing language skills also means training thinking skills.

Writing is a productive and expressive activity. There are several opinions of experts regarding the meaning of writing. Tarigan said, "Writing is imitating or painting graphic symbols that describe a language that is understood by someone, so that other people can read the graphic symbols if they understand the language and the graphic description." Pictures or paintings may convey meanings, but do not represent language units. Writing is a representation of part of these language units. Writing is a representation of part of the units of language expression. In writing activities, another important thing that must be considered is the flow. The flow of writing is usually made to fulfill a specific purpose. So, every writer often formulates the purpose of writing in advance.

The formulation of the purpose of writing is a comprehensive picture or plan that will direct the next writing. In determining the purpose of writing, the writer knows what to do. Septiawan argues, "A writer who has a mature writing goal will not experience a deadlock of ideas. He always knew what was written in his writings. Writing is very important, because writing can be a medium for someone to express thoughts or feelings in written form such as composing, writing letters, and so on.

\section{Methods}

In this study, researchers used the method used in this study is the experimental method. In addition, this research method is also widely chosen because this research is the most productive. The experimental method used by researchers in this study is a quasi-experimental research design (quasi-experimental design). According to Sugiyono (2013: 77), "Quasi experimental design is a design that has a control group, but cannot function fully to control external variables that affect the implementation of experiments". A quasiexperimental design can be used to overcome difficulties in determining the control group in the study. Sulaeman. A. (2019: 45) In a quasiexperimental design, the research carried out still uses the control class and the experimental class as a comparison. The experimental class was given the treatment in the form of a flash card in the short story writing lesson, while the control class was given the same material but using conventional learning methods. The design used in this study is the Nonequivalent Control Group Design, this design is almost the same as the pretest-posttest control group design, except that in this design the experimental group and control group are not chosen randomly.

\section{Results and Discussion}

\section{A. Data Description}

The data described are data obtained from the results of filling out tests using developed instruments. The presentation of the data is intended to provide an overview of the size of the data concentration and the size of the data spread. The data is presented in the form of a frequency distribution table and in the form of a graph to make it more communicative and easy for readers to understand.

Based on the results of the control class pretest at SMP Aruslan, Sukamulya, Tangerang Regency, for the 2020/2021 school year. The data obtained from the respondents are as follows: The lowest score obtained in the control class is 50 and the highest score is 70. Students who scored $50-52$ were 4 students. Value $53-55$ as many as 6 students. Value 56 - 58 as many as 2 students. Value 59 - 61 as many as 9 students. Value 62 - 64 as many as 5 students. Values 65 - 67 as many as 2 students. The value of 68 - 70 as many as 6 students. For more details, see the frequency distribution table below. 
Table 4.1

Frequency Distribution of Control Class Pretest

\begin{tabular}{ccccc}
\hline Class & Interval & Class range & $\begin{array}{c}\text { Frequency of } \\
\text { Absolute }\end{array}$ & F Relative (FR)\% \\
\cline { 2 - 2 } & BBK BAK & & 4 & $11,76 \%$ \\
\hline $\mathbf{1}$ & $50-52$ & $49,5-52,5$ & 6 & $17,64 \%$ \\
\hline $\mathbf{2}$ & $53-55$ & $52,5-55,5$ & 2 & $5,88 \%$ \\
\hline $\mathbf{3}$ & $56-58$ & $55,5-58,5$ & 9 & $26,47 \%$ \\
\hline $\mathbf{4}$ & $59-61$ & $58,5-61,5$ & 5 & $14,70 \%$ \\
\hline $\mathbf{5}$ & $62-64$ & $61,5-64,5$ & 2 & $5,88 \%$ \\
\hline $\mathbf{6}$ & $65-67$ & $64,5-67,5$ & 6 & $17,64 \%$ \\
\hline $\mathbf{7}$ & $68-70$ & $67,5-70,5$ & 34 & $100 \%$ \\
\hline
\end{tabular}

From the frequency distribution table, the data is then presented in the form of histogram graphs and polygon graphs. The form of data presentation that describes the ebb and flow of statistical data. The presentation of this data is so easy for readers to understand with the data obtained in the control class as follows: The data range is $49.5-52.5$ as many as 4 students. The data range is $52.5-55.5$ as many as 6 students. The data range is $55.5-58.5$ as many as 2 students. The data range is $58.5-61.5$ as many as 9 students. The range of data is $61.5-$ 64.5 as many as 5 students. The data range is $64.5-67.5$ as many as 2 students. The data range is $67.5-70.5$ as many as 6 students.

\section{B. Research Discussion}

Based on the research findings above. As stated in the pretest frequency distribution table for the control class, the highest frequency lies in the interval $59-61$ by $26.47 \%$, with the average value obtained in the control class as much as 60.08 , the frequency is above the average of $26.47 \%$. While below the average value of $5.88 \%$. In the pretest frequency distribution table for the experimental class, the highest frequency lies in the 70-75 interval of $38.70 \%$, with the average value obtained in the control class as much as 71.81 , the frequency is above the average of $38.70 \%$. While below the average value of $6.45 \%$.

\section{Tabel 4.2}

\begin{tabular}{llllll}
\hline \multicolumn{1}{c}{ Class } & $\begin{array}{c}\text { Frequency } \\
\text { range }\end{array}$ & Presentage & $\begin{array}{c}\text { Average } \\
\text { (mean) }\end{array}$ & Higher score & Lower score \\
\hline Control & $59-61$ & $26,47 \%$ & 60,08 & $26,47 \%$ & $5,88 \%$ \\
\hline Experiment & $70-75$ & $38,70 \%$ & 71,81 & $38,70 \%$ & $6,45 \%$ \\
\hline
\end{tabular}

Based on the table above, the differences between the two classes can be seen. The highest presentation was in the experimental class of $38.70 \%$, and the control value was $35 \%$. The value above the average for the control class is $26.47 \%$ while in the 
experimental class it is higher at $38.70 \%$. The value below the average for the control class is $5.88 \%$, while the value below the average for the experimental class is $6.45 \%$. So it can be seen that the values in the control class are slightly lower. The difference is in the values above the average and below the average.

While the histogram graph in the description above, it can be seen that the histogram graph of the highest control class pretest graph is located at a value of 58.5 as many as 19 respondents. The highest score was 70.5 with 6 respondents, while the lowest score was 49.5 with 4 respondents. In the histogram graph of the experimental class the highest graph is located at a value of 70.5 with 12 respondents.

The highest score was 80.5 with 2 respondents, while the lowest score was 60.5 with 2 respondents.

For the posttest frequency distribution, the control class has the highest frequency at intervals of $61-65$ by $26.47 \%$, with the average value obtained in the control class as much as 56.91, the frequency is above the average of $26.47 \%$. While below the average value of $5.88 \%$. In the posttest frequency distribution table for the experimental class, the highest frequency lies in the interval $74-76$ of $22.58 \%$, with the average value obtained in the control class as much as 72.58 , the frequency is above the average of $232.25 \%$. While below the average value of $6.45 \%$.

Tabel 4.3

\begin{tabular}{llllll}
\hline Class & Frequency range & Presentage & $\begin{array}{l}\text { Average } \\
\text { (mean) }\end{array}$ & $\begin{array}{l}\text { Higher } \\
\text { score }\end{array}$ & Lower score \\
\hline Control & $61-65$ & $26,47 \%$ & 56,91 & $26,47 \%$ & $6,45 \%$ \\
\hline Experiment & $74-76$ & $22,58 \%$ & 72,58 & $232,25 \%$ & $5,88 \%$ \\
\hline
\end{tabular}

Based on the table above, the differences between the two classes can be seen. The highest presentation was in the experimental class of $22.58 \%$, and the control value was $26.47 \%$. The value above the average for the control class is $26.47 \%$, while in the experimental class it is higher at $232.25 \%$. The value below the average for the control class is $6.45 \%$, while the value below the average for the experimental class is $5.88 \%$. So it can be seen that the values in the control class are slightly lower. The difference is in the values above the average and below the average.

While the histogram graph in the description above, it can be seen that the histogram graph of the posttest control class, the highest graph is located at a value of 63.5 with 13 respondents. The highest score is 75.5 with 2 respondents, while the lowest value is 54.5 with 2 respondents. In the posttest histogram graph of the experimental class, the highest graph is located at a value of 73.5 with 13 respondents. The highest score was 85.5 with 3 respondents, while the lowest score was 64.5 with 2 respondents.

Based on the results of the pretest of the control class and the experimental class, the mean value (average) is a measure that gives an idea of the concentration of a data to determine the average value of a statistical data. The mean (average) value for the control class is (60.08), while in the experimental class the mean (average) value is (71.87). Meanwhile, at the time of post-test control class and experimental class, the mean value in the control class was (56.91), and in the experimental class the mean 
value (72.58). For more details, see the table

below:

Grafik 4.1

Nilai Rata - Rata Pretes Dan Postes Kelas Kontrol Serta Kelas Eksperimen

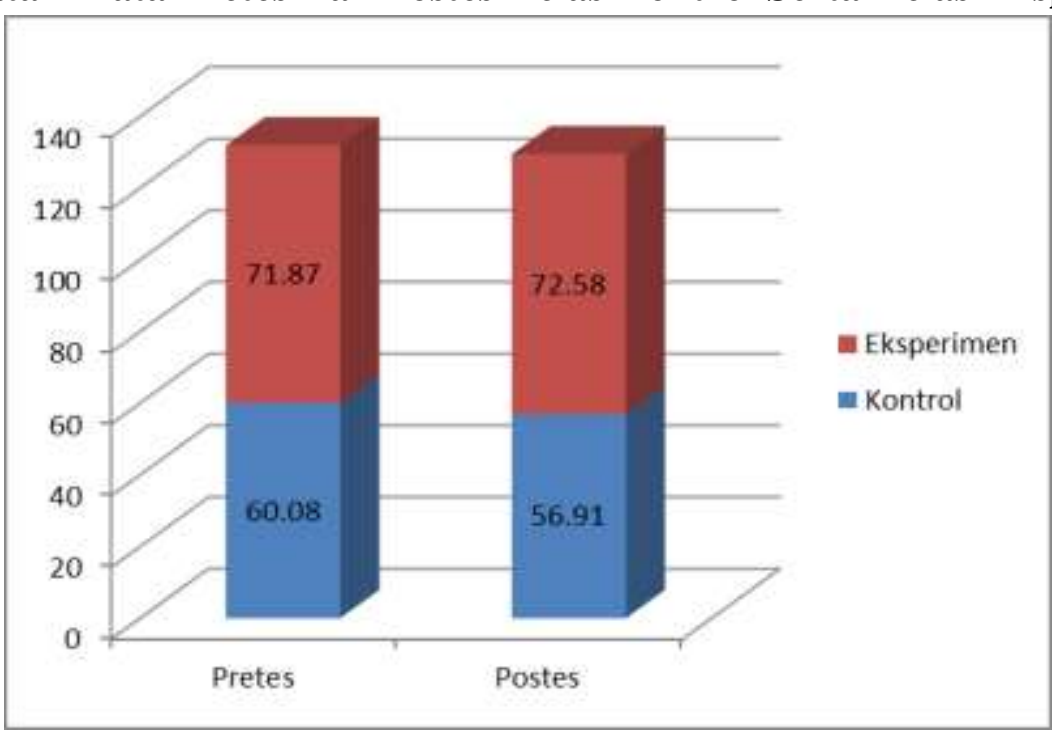

Based on the graph above, the pretest data for the control class and the experimental class showed a significant difference. It can be seen from the graph height which is slightly far from the average. This is influenced because at the time of the pretest the researcher did not use treatment so that the students did not understand how to write short stories.

From the post-test data the control and experimental classes showed a significant difference. It can be seen from the graph height of the two classes. The experimental class graph is higher than the research experimental graph giving treatment using (image media) while the research control class does not provide treatment so that there are differences in learning outcomes in the control class and in the experimental class.

Furthermore, to find out whether there is an effect on the pretest data of the control class and the experimental class. The researcher conducted a t-test to find out whether there were differences in the two classes. After doing the calculations, it was obtained that tcount $7.67<$ ttable 1.99 so that it can be concluded that there is no difference in learning outcomes between the control class and the experimental class. This is because at the time of the pretest the researcher did not use the media (treatment). So that students are less able to write short stories. Likewise, the results of the posttest research conducted a t-test to find out whether there were differences in the two classes. After calculating the results obtained tcount $2.48>$ ttable 1.99 . So it can be concluded that there are differences in learning outcomes between the control class and the experimental class.

\section{Conclusion}

Based on the results of data analysis, the flash card media can improve students' short story writing skills for class VIII SMP Aruslan Sukamulya District, Tangerang Regency for the 2020/2021 academic year The average posttest 
student score is higher than the student's pretest score. The average value of the posttest obtained is 70 , while the average value of the pretest obtained by the students is 50 .

The effect of the flash card media is seen when calculating the hypothesis using a hypothesis test which shows a significant difference between the posttest score and the students' pretest score. From the hypothesis test, it can be seen that the results of tcount 2.47 $>$ ttable 1.99. So it can be concluded that there are differences in learning outcomes between the control class and the experimental class. So the hypothesis that has been carried out by the researcher is accepted. Responses or student responses to the media picture card (flash card) by $80 \%$. It means that students feel that the flash card media is suitable for use in writing short stories.

Teachers can use the media with picture cards (flash cards) as a renewal material for Indonesian language learning, especially in essay writing skills. With the media of picture cards (flash cards), students' ability to write can be developed properly. With various limitations, what is produced in this study is not the final result. The limitations and shortcomings of this study can be used as the basis for further research, with the hope of finding out whether learning using flash cards can be applied and provide better results in Indonesian language lessons with different materials.

\section{Acknowlegment}

The researcher would like to thank the head of the Indonesian Language and Literature Education Study Program, colleagues in the Indonesian Language and Literature Education Study Program and all parties involved in this research. Hopefully this research will contribute to literary theory, especially the field of linguistics in literature.

\section{References}

Arief S. Sadiman, dkk. (2010). Media Pendidikan. Jakarta: PT Raja Grafindo Persada.

Arikunto, Suharsimi. (2010). Prosedur Penelitian Suatu Pendekatan Praktik. Jakarta: PT. Rineka Cipta.

Arsyad, Azhar.( 2011). Media Pembelajaran. Jakarta: PT Raja Grafindo Persada.

Aziez, Furqonul dan Abdul Hasim. (2010). Menganalisis Fiksi Sebuah Pengantar. Bogor: Ghalia Indonesia.

Daryanto. (2011). Media Pembelajaran. Bandung: PT. Sarana Tutorial Nurani Sejahtera.

Hasani, Aceng. (2005). Ihwal Menulis. Serang: UNTIRTA PRESS.

Kosasih, E. (2012). Dasar-Dasar Keterampilan Bersastra. Bandung: CV. Yrama Widya.

Riadi, Edi. (2014). Metode Statistik Parametrik \& Nonparametik. Tangerang: Pustaka Mandiri.

Sabarti Akhadiah, dkk. (2012). Pembinaan Kemampuan menulis Bahasa Indonesia. Jakarta: Erlangga.

Sudjana, Nana dan Rivai, Ahmad. (2011). Media Pengajaran. Bandung: Sinar Baru Algensindo.

Sudjana, Nana. (2009). Penilaian Hasil Proses Belajar Mengajar. Bandung: PT. Remaja Rosdakarya. 
Sugiyono. (2013). Metode Penelitian Kuantitatif, Kualitatif, dan $R \& D$. Bandung: CV. Alfabeta.

Sugiyono. (2013). Statistik untuk Penelitian. Bandung: CV. Alfabeta.

Sulaeman, A. Goziyah. 2019. Metodologi Penelitian Bahasa dan Sastra. Jakarta Timur: Edu Pustaka.

Sulaeman, A., \& Dwihudhana, W. (2019). Hubungan Motivasi Belajar dengan Hasil Pembelajaran Bahasa Indonesia bagi Penutur Asing (BIPA) pada Mahasiswa Semester 7 Program Studi Pendidikan Bahasa dan Sastra Indonesia FKIP Universitas Muhammadiyah Tangerang. Silampari Bisa: Jurnal Penelitian Pendidikan Bahasa Indonesia, Daerah, dan Asing, 2(1), 59-70.

Sulaeman, A., Hun, K. Y., \& Ferdianda, A. Ecocritics In Song Lyrics Collection By Barasuara And Its Implication Towards The Indonesian Language Learning Material In Senior High School (Kumpulan Lirik Lagu Barasuara Band Karya Iga Dada Yudhistira Massardi Dan Implikasi Dengan Materi Pembelajaran Bahasa Indonesia Di Sekolah Menengah Atas Kajian Ekokrtik Sastra).

Sumardjo, Jakob. (20070. Menulis Cerpen. Yogyakarta: Pustaka Pelajar.

Tarigan, Henry Guntur. (2008). Menulis Sebagai Suatu Keterampilan Berbahasa. Bandung: Angkasa. 